\title{
A Systematic Literature Review on Traumatic Optic Neuropathy
}

\author{
Saeed Karimi $\mathbb{D}^{1,2}$ Amir Arabi $\mathbb{D}^{1,2}$ Iman Ansari $\mathbb{D}^{1,2}$ Toktam Shahraki $\mathbb{D},{ }^{1,2}$ \\ and Sare Safi $\mathbb{D}^{3}$ \\ ${ }^{1}$ Ophthalmic Research Center, Research Institute for Ophthalmology and Vision Science, \\ Shahid Beheshti University of Medical Sciences, Tehran, Iran \\ ${ }^{2}$ Department of Ophthalmology, Torfeh Medical Center, Shahid Beheshti University of Medical Sciences, Tehran, Iran \\ ${ }^{3}$ Ophthalmic Epidemiology Research Center, Research Institute for Ophthalmology and Vision Science, \\ Shahid Beheshti University of Medical Sciences, Tehran, Iran
}

Correspondence should be addressed to Iman Ansari; imnansari71@gmail.com

Received 14 January 2021; Revised 14 February 2021; Accepted 18 February 2021; Published 26 February 2021

Academic Editor: Arturo Carta

Copyright (C) 2021 Saeed Karimi et al. This is an open access article distributed under the Creative Commons Attribution License, which permits unrestricted use, distribution, and reproduction in any medium, provided the original work is properly cited.

Traumatic optic neuropathy (TON) is an uncommon vision-threatening disorder that can be caused by ocular or head trauma and is categorized into direct and indirect TON. The overall incidence of TON is $0.7-2.5 \%$, and indirect TON has a higher prevalence than direct TON. Detection of an afferent pupillary defect in the presence of an intact globe in a patient with ocular or head trauma with decreased visual acuity strongly suggests TON. However, afferent pupillary defects may be difficult to detect in patients who have received narcotics that cause pupillary constriction and in those with bilateral TON. Mechanical shearing of the optic nerve axons and contusion necrosis due to immediate ischemia from damage to the optic nerve microcirculation and apoptosis of neurons is a probable mechanism. The proper management of TON is controversial. High-dose corticosteroid therapy and decompression of the optic nerve provide no additional benefit over observation alone. Intravenous erythropoietin may be a safe and efficient treatment for patients with TON.

\section{Introduction}

Traumatic optic neuropathy (TON) is a vision-threatening disorder that can be caused by either ocular or head trauma and is categorized into direct and indirect TON $[1,2]$. Direct TON is frequently associated with severe visual loss and a lower chance of recovery compared to indirect TON [2]. Direct TON often occurs when the optic nerve is lacerated with bone fragments or when contusion or concussion causes anatomical disruption $[2,3]$. In contrast, indirect TON often occurs when a blunt head or ocular traumatic stress is transmitted through the oculofacial soft tissues and skeleton to the optic nerve; this damages the integrity of the optic nerve, leading to mild-to-severe vision loss $[2,4,5]$. It usually occurs at the junction of the intraorbital and intracanalicular segments causing compression and disruption of the pial vessels, thereby reducing the vascular supply of the optic nerve $[6,7]$.

\section{Materials and Methods}

The literature published from 1950 to March 2020 was reviewed by searching the ISI Web of Knowledge database, PubMed, Scopus, Embase, and the Cochrane Library. The following keywords were used: "traumatic optic neuropathy," "TON," "treatment," "direct TON," "indirect TON," "pathogenesis," and "prognosis." No language limitations were applied. Articles and meta-analyses that published information about TON were selected through review of abstracts, references, and titles.

\section{Results}

3.1. Epidemiology. TON is an unusual cause of visual impairment after blunt or penetrating head trauma. The overall incidence of TON is $0.7-2.5 \%$ [8-11]. Indirect TON has a higher prevalence than direct TON. It occurs in $0.5 \%$ to $5 \%$ 
of all patients with closed head injury and $2.5 \%$ of patients with midfacial fractures $[5,12]$. Intracanalicular part is the most common site of indirect TON (71.4\%), followed by the orbital apex (16.7\%). Involvement of both the intracanalicular segment and orbital apex was found in $11.9 \%$ of the cases. The intracranial portion of the optic nerve adjacent to the falciform ligament is another common site for optic nerve traumatic injury $[13,14]$.

TON has a gender predominance. Up to $80 \%$ of patients with TON have been reported to be male with a median age of 31 years, and $21 \%$ are younger than 18 years [11, 15]. Having a fall (26\%), motor vehicle accidents (21\%), and assaults $(21 \%)$ are common etiologies of TON in the general population. However, in trauma settings, motor vehicle accidents (63\%) and falling down are the main etiologies $[11,15]$. TON occurs in $0.4 \%$ of patients with any kind of trauma [15]. There is a prominent association between TON and head injury, wherein all patients with TON have head injuries (two-thirds of them have a significant head injury). However, only $2.3 \%$ of the patients with head trauma experience concomitant TON [15]. Epidemiologic features of TON in pediatric patients are similar to those in adults [16]. Having a fall (50\%) and motor vehicle accidents (40\%) are the most common causes of TON in the pediatric population [17].

3.2. Pathogenesis. The pathophysiology of TON is not yet fully understood, but several mechanisms have been proposed. TON cases can be categorized as primary or secondary. Mechanical shearing of the optic nerve axons and contusion necrosis due to immediate ischemia from damage to the optic nerve microcirculation are primary mechanisms, while apoptosis of both injured and initially intact adjacent neurons is the mainstay of secondary TON $[2,4,18]$. Many patients have the involvement of both mechanisms to a certain degree.

An essential part of the pathophysiology of indirect TON is the effect of traumatic loads on the biomechanical response of the cranial contents. One study using holographic interferometry on human skulls suggested that damage to the frontal region deforms the ipsilateral orbital roof, causing damage to the optic nerve and its supporting vasculature, especially where the nerve enters the optic canal [7]. Based on an anatomic study of cadaveric orbits and optic nerves, direct shearing injury to axons, disruption of the blood supply, and pressure from microhematomas and edema due to the damage of anastomoses running between the dura and pia are the possible mechanisms of optic nerve damage [19].

Another mechanism that is thought to be involved in TON is diffuse axonal injury. Detrimental inertial forces to the head cause diffuse axonal damage, which is associated with poor neurological outcomes. Following head injury, axons of the brain white matter become rapidly deformed, resulting in axonal cytoskeleton damage and impaired axoplasmic transmission [20].

It is necessary to improve the present knowledge about the association between the biomechanics and pathophysiology related to axonal trauma. Data from trauma modeling in a virtual head and orbit show that trauma to the frontal region, even at low intensity, transmits toward the optic foramen, resulting in indirect TON. This finding supports the theory that indirect TON is more likely to be caused by a facial injury, rather than trauma to the skull. Despite this progress, the mechanism of indirect TON remains unknown. A holistic model of the orbit, containing both bone and soft tissue components, will be an excellent tool to study the pathophysiology of this vision-threatening disorder and may help develop approaches for its prevention and mitigation [21].

\subsection{Diagnosis}

3.3.1. Clinical Finding. In patients with craniofacial trauma and normal globe and optic nerve head appearance, any evidence of optic nerve dysfunction (reduced vision and an afferent pupillary defect) suggests the diagnosis of indirect TON $[2,4]$. Clinical findings that help diagnose TON include (1) ocular injury, (2) a relative afferent pupillary defect (RAPD), (3) variable degrees of vision loss, (4) color vision disorder, and (5) different degrees of visual field defects. RAPD is a valuable finding, and in cases with mild TON, it may be the only clinical finding before overt optic nerve atrophy. The fact that RAPD is negative in bilaterally symmetric cases should be considered. Visual acuity (VA) may range from normal to no light perception, and $40-60 \%$ of cases have light perception or worse at the time of first ophthalmic visit. Although the poor VA of the patients may not allow the ophthalmologist to attain valuable results, automated visual field testing should be offered in feasible circumstances [15, 22-24].

Anatomical location and the timing of damage are factors that determine the optic disc involvement and appearance. In most cases, the posterior part of the optic nerve is damaged, and the optic disc is often normal. In cases where the optic nerve is damaged anterior to the entry site of the central retinal vessels, swelling of the optic disc and retinal hemorrhage are evident on examination of the optic nerve head. Independent of the initial appearance of the optic disc, atrophy and pallor of the optic nerve occur approximately six weeks after the initial injury [25].

3.3.2. Imaging. There is a controversy about the role of neuroimaging in TON diagnosis. Some physicians prefer to perform computed tomography (CT) scan and magnetic resonance imaging $(\mathrm{MRI})$ in all patients, while the others preserve imaging modalities for cases with progressive visual impairment or when therapeutic interventions are being considered [26-28]. As such, patients with head or oculofacial trauma and simultaneous symptoms of optic nerve damage (unilateral or bilateral decreased VA, visual field defect, and an afferent pupillary defect on examination) should undergo urgent radiological investigations [29]. 
3.3.3. CT Scan. CT is the best and most accessible imaging method for detecting optic canal fractures, orbital wall fractures, and the presence of blood in the orbit. It is very helpful in diagnosing direct or indirect TON and can also be used as a guide map for surgical interventions. It is observed that in patients with indirect TON and posterior orbital fractures, the prognosis is poorer than that in patients with indirect TON and anterior orbital fractures, suggesting a prognostic value for CT scan $[25,29,30]$.

3.3.4. MRI. Although MRI is not as readily available as CT in trauma settings, it can be very helpful in evaluating the optic nerve integrity and detecting nerve sheath hematoma [29]. However, MRI should be avoided if a retained metallic foreign body may be suspected when trauma is occurring. Different MRI techniques are useful in the diagnosis and follow-up of patients with indirect TON. In a study by Bodanapally et al., it was shown that optic nerve hyperintensity on diffusion-weighted imaging can be helpful in diagnosing indirect TON [31]. In another study, the diffusion tensor imaging technique showed no finding in the first week after injury, but by the second week, fractional anisotropy reduction became visible in the damaged eye and continued to be visible after one month [32]. These findings show that MRI is beneficial to detect changes in the later stages, but may not be as useful as CT in the early phases.

3.3.5. Visual Evoked Potential. Although in many patients, the use of visual evoked potential (VEP) is not required to diagnose TON, it can be helpful in the diagnosis of suspicious cases and for determining the prognosis of vision. VEP has diagnostic value in patients who do not remember the time of nerve damage, patients with unreliable pupillary responses, and patients with bilateral TON. The chances of vision recovery are higher in patients with better responses to VEP [33-35]. Pattern reversal and flash VEP testing have been used to determine the rate of vision recovery. It has been reported that patients with a VEP amplitude of $50 \%$ in the damaged eye will have good vision recovery, while patients with an absent VEP will not have a good final vision [35-37]. Despite the diagnostic and predictive value of VEP, it has some limitations. For example, it is difficult to place a VEP device to the bedside of patients with multiple injuries in special wards. Patients may also have a concurrent brain injury, which can be mistaken for optic nerve damage, and this issue should not be dismissed [38].

3.3.6. Optical Coherence Tomography. Several studies using optical coherence tomography (OCT) have shown retinal nerve fiber layer thinning in patients with TON. However, given that this finding may not be detected in the early stages and it is difficult to sit the patient up to do the OCT imaging, the value of OCT in the diagnosis of TON is reduced. OCT may be valuable in the long-term follow-up to show the progression of optic nerve injury over time [39-41].
3.3.7. Doppler Sonography. Ultrasound Doppler has been employed in patients with TON to assess the hemodynamic indices of the central retinal artery (CRA). The reduction of peak systolic velocity (PSV), end-diastolic velocity (EDV), and time-average mean velocity (TAMX) have been reported in TON eyes [42]. This finding was confirmed by another study that showed reduction of PSV and EDV in the CRA of the injured eye [43].

3.3.8. Visual Field. Although the visual acuity of patients with TON may be too poor which reduces the likelihood of achieving an acceptable outcome, automated visual field testing should be considered in all patients [21]. There is no specific visual field defect in patients with TON and any visual field impairment has been reported in patients; however, arcuate, central, and hemianopic field defects may be seen [29]. It is well documented that the visual field is severely compromised at baseline when it is compared with normal subjects, but a comparison of baseline visual field and long-term follow-up visit shows a significant improvement in visual field extension [44].

\subsection{Treatment}

3.4.1. Medical Treatment of TON. A visual recovery rate of about $50 \%$ is expected following conservative management in indirect TON, where baseline VA plays the main role in the prediction of final visual outcome [22, 45-47]. To estimate the golden time of medical or surgical treatment, a longitudinal study by Kanamori et al. was performed to analyze the decrease in ganglion cell population and nerve fiber layer thickness following TON [48]. They reported that the decrease started two weeks after trauma and stopped changing after 20 weeks. Accordingly, it was suggested that the treatment should be started within 20 weeks following the incidence of TON.

The pharmacological rationale of using corticosteroids for TON arose from their benefits in the management of CNS injuries in animal models $[13,49]$. According to these studies, it was hypothesized that steroids exert neuroprotective effects through their antioxidant properties [50]. Animal models of steroid efficacy for the treatment of TON, however, yielded inconclusive observations. Ohlsson et al. failed to show any effectiveness of steroid therapy on retinal axon and ganglion cell survival [51]. In another study, it was found that steroids exacerbated axonal loss following optic nerve damage in a dose-dependent fashion [52]. However, Lew et al. reported an improved optic nerve blood flow following high-dose corticosteroid therapy in 10 rabbits with experimental TON [53].

Considering human studies, the use of high-dose corticosteroids for TON was extrapolated from the National Acute Spinal Cord Injury Study (NASCIS) results [54]. Although the debate surrounding the NASCIS results has never come to a conclusion, a review by one of the investigators of the NASCIS supported the idea that steroids help in neurological salvage when administered within 8 hours of spinal cord injury [55]. 
Table 1 summarizes some studies on the effectiveness of steroids for the treatment of TON. The International Optic Nerve Trauma Study (IONTS) is the largest comparative study analyzing 133 cases of indirect TON treated with corticosteroids, surgical decompression of the optic nerve, and observation. Following adjustment for baseline VA, there were no significant differences between the three groups. Neither the dose nor the timing was associated with a higher probability of visual recovery. The improvement rates reported by other case series for steroid therapy in TON are comparable to IONTS, being around 50\%.

In a placebo-controlled clinical trial, 31 eyes of 31 patients were divided into two management groups. Sixteen eyes received $250 \mathrm{mg}$ intravenous methylprednisolone $\mathrm{q} 6 \mathrm{~h}$ for 3 days, followed by oral administration of $1 \mathrm{mg} / \mathrm{kg}$ prednisolone for 14 days; the other 15 eyes received a placebo [62]. The study confirmed previous observations that there is no difference in VA improvement between steroids and placebo in the treatment of TON.

In a pilot study in 2011, 7 cases with indirect TON received daily intravenous injections of 10,000 IU erythropoietin (EPO) for three days. They were compared to eight patients who received no specific treatment [65]. The final VA was significantly higher in the EPO group, suggesting a new safe and efficient treatment for patients with TON. In another case series, 18 eyes of 18 indirect TON patients received 20,000 IU EPO daily injections for three consecutive days [66]. This study reported an obvious effect of EPO on improvement of VA in patients with recent indirect TON.

In the Traumatic Optic Neuropathy Treatment Trial (TONTT), 120 patients underwent treatment with EPO, methylprednisolone, or observation [67]. Although color vision was reported to improve in the EPO group, improvement of VA was not significantly different between the three groups.

Complications of steroid and EPO treatment are rare; however, there is no definite evidence of any benefits of these drugs in terms of VA improvement in patients with TON. Thus, clinicians should be aware of the risk of severe side effects with an aggressive treatment protocol, especially when the effectiveness of the treatment is under debate. The Corticosteroid Randomization after Significant Head Injury (CRASH) study was terminated prematurely due to the increased rate of death in the high-dose corticosteroid group [68]. The Optic Neuritis Treatment Trial reported two cases of acute psychosis and acute pancreatitis in the steroid treatment group, both resolving without sequelae [69]. Transient hypotension has been reported in studies with EPO, which can be hazardous for patients with multiple trauma and unstable medical conditions [66].

3.4.2. Surgical Treatment of TON. Regarding VA improvement TON cases, the effectiveness of surgical interventions is similar to that of medical therapies. However, surgical procedures may be superior to medical management since they can be performed according to pretreatment indications and be scheduled for selected patients. In addition, optimal surgical techniques have been investigated and updated through numerous studies performed by ophthalmologists, neurosurgeons, and head and neck surgeons.

Releasing the compression exerted by edema, hematoma, or fractured bone segments on the optic nerve is the rationale for surgery in TON. It can be indicated in the following situations: presence of bone segments or hematoma compressing the nerve in initial posttrauma images, poor response to initial medical treatment, evidence of optic nerve damage in preoperative VEP scan, or lack of evident damage to ocular tissues and intracranial optic nerve [70].

According to primary reports, it was recommended to perform surgery within 2 or 3 days following the trauma $[71,72]$. However, in a recent meta-analysis, more than half of the patients treated surgically after seven days experienced visual improvement, and it was comparable with the early treatment group who underwent surgery within three days [73]. Accordingly, it may be recommended that in selected patients with appropriate indications, late surgical intervention is better than not intervening. Apparently, complete atrophy of the nerve, disruption of the intracranial portion of the ON, presence of carotid-cavernous fistula, and unstable systemic condition for general anesthesia should be considered as contraindications for any kind of surgical intervention [70].

The three main approaches performed for decompression of the optic nerve include medial transorbital and external ethmoidectomy, transcranial surgery, and endoscopic transnasal approach. Classic transorbital and transcranial approaches have been criticized for cosmetic problems; however, the main advantage of these procedures is the surgical view and wide optic nerve decompression. In contrast, transnasal approaches do not have cosmetic concerns, but relatively narrow decompression of the optic nerve may restrict optimal surgical outcomes. Between these two extremes of the surgical spectrum, some modification to surgical decompression of the optic nerve have been proposed. As a modification to the classic transcranial approach, the supraorbital approach may be performed through extradural unroofing of the optic canal via an endoscope $[74,75]$. To overcome the limitations associated with the endonasal approach, total circumference decompression of the ON through a combined transorbital and transnasal approach is being developed [76].

Since the trend of optic nerve decompression has turned toward endoscopic approaches, Table 2 is presented to summarize some case series evaluating the efficacy of the procedure, in addition to presenting surgical indications and predictive pretreatment factors.

3.5. Prognosis. Direct and indirect TON have different prognoses. Direct TON causes severe, permanent visual impairment with slight probability for recovery [25], while visual recovery happens in $40-60 \%$ of cases with indirect TON that are managed conservatively. It is reported that in patients with indirect TON the visual function spared, if any, three months after trauma is maintained virtually forever in 
TABLE 1: Summary of the studies on the effectiveness of steroids for the treatment of TON.

\begin{tabular}{|c|c|c|c|c|c|}
\hline Study & Type of the study & Year & $\begin{array}{c}\text { Number of } \\
\text { eyes }\end{array}$ & Treatment protocol & Study result \\
\hline Spoor et al. [56] & $\begin{array}{c}\text { Comparative } \\
\text { observational } \\
\text { study }\end{array}$ & 1990 & $\begin{array}{l}22 \text { eyes } \\
\text { from } 21 \\
\text { patients }\end{array}$ & $\begin{array}{l}13 \text { patients were treated with } \\
\text { intravenous megadose } \\
\text { methylprednisolone, } 8 \text { patients were } \\
\text { treated with high-dose } \\
\text { dexamethasone }\end{array}$ & $\begin{array}{l}12 \text { of } 13 \text { patients from } \\
\text { methylprednisolone group and } 7 \text { of } \\
9 \text { eyes from dexamethasone group } \\
\text { experienced improved visual } \\
\text { function } \\
\text { The difference between two group } \\
\text { was not significant }\end{array}$ \\
\hline Seiff [47] & $\begin{array}{l}\text { Comparative } \\
\text { observational } \\
\text { study }\end{array}$ & 1990 & 36 & $\begin{array}{l}21 \text { patients were acutely treated with } \\
\text { high-dose intravenous } \\
\text { dexamethasone and } 15 \text { were not }\end{array}$ & $\begin{array}{l}62 \% \text { of the treated patients and } 33 \% \\
\text { of the untreated patients showed } \\
\text { visual improvement } \\
\text { The difference was not statistically } \\
\text { significant }\end{array}$ \\
\hline Maureillo et al. [57] & $\begin{array}{l}\text { Non-comparative } \\
\text { observational } \\
\text { study }\end{array}$ & 1992 & 23 & $\begin{array}{l}\text { High-dose intravenous steroids were } \\
\text { initiated in all patients } \\
\text { If vision did not improve } \\
\text { significantly after } 24 \text { to } 48 \text { hours, } \\
\text { decompression of the optic nerve was } \\
\text { considered }\end{array}$ & $\begin{array}{c}\text { Nine of } 16 \text { patients who received } \\
\text { steroids only showed significant } \\
\text { improvement }\end{array}$ \\
\hline Chou et al. [45] & $\begin{array}{l}\text { Comparative } \\
\text { observational } \\
\text { study }\end{array}$ & 1996 & 58 & $\begin{array}{l}23 \text { patients were treated with } \\
\text { intravenous dexamethasone or oral } \\
\text { prednisolone; } 25 \text { patients underwent } \\
\text { optic canal decompression in } \\
\text { addition to medical treatment }\end{array}$ & $\begin{array}{l}13 \text { of the } 23 \text { cases ( } 57 \%) \text { in the } \\
\text { medical group had visual } \\
\text { improvement } \\
15 \text { of } 25 \text { cases }(60 \%) \text { in the surgical } \\
\text { group had visual improvement; } \\
\text { none of the control patients showed } \\
\text { any improvement in visual acuity }\end{array}$ \\
\hline Levin et al. [22] & $\begin{array}{l}\text { Comparative } \\
\text { observational } \\
\text { study }\end{array}$ & 1999 & 133 & $\begin{array}{c}9 \text { patients received no treatment, } 85 \\
\text { patients were treated with } \\
\text { corticosteroids, and } 33 \text { patients } \\
\text { underwent optic canal } \\
\text { decompression }\end{array}$ & $\begin{array}{l}32 \% \text { of the surgery group, } 57 \% \text { of the } \\
\text { untreated group, and } 52 \% \text { of the } \\
\text { steroid group showed visual } \\
\text { improvement; there were no } \\
\text { significant differences between any } \\
\text { of the treatment groups }\end{array}$ \\
\hline Wang et al. [23] & $\begin{array}{l}\text { Comparative } \\
\text { observational } \\
\text { study }\end{array}$ & 2001 & 61 & $\begin{array}{l}25 \text { patients treated with high-dose } \\
\text { steroids, } 7 \text { patients underwent optic } \\
\text { nerve decompression, } 13 \text { received no } \\
\text { treatment, and others underwent } \\
\text { facial surgery }\end{array}$ & $\begin{array}{l}\text { There was no significant difference } \\
\text { in the improvement of visual acuity } \\
\text { in patients treated with surgical } \\
\text { versus nonsurgical methods }\end{array}$ \\
\hline Kitthaweesin [58] & $\begin{array}{l}\text { Comparative } \\
\text { observational } \\
\text { study }\end{array}$ & 2001 & 21 & $\begin{array}{l}10 \text { patients received dexamethasone } \\
\text { intravenously, and } 11 \text { received } \\
\text { intravenous methylprednisolone }\end{array}$ & $\begin{array}{l}70 \% \text { of patients treated with } \\
\text { dexamethasone, and } 45 \% \text { of patients } \\
\text { treated with methylprednisolone } \\
\text { experienced visual improvement } \\
\text { There were no significant differences } \\
\text { in the visual improvement between } \\
\text { the two groups }\end{array}$ \\
\hline $\begin{array}{l}\text { Chuenkongkaew } \\
\text { and Chirapapaisan } \\
\text { [59] }\end{array}$ & $\begin{array}{l}\text { Comparative } \\
\text { observational } \\
\text { study }\end{array}$ & 2002 & 44 & $\begin{array}{l}22 \text { patients selected to receive } \\
\text { intravenous high-dose } \\
\text { dexamethasone, and } 20 \text { cases } \\
\text { received megadose } \\
\text { methylprednisolone }\end{array}$ & $\begin{array}{l}\text { Visual improvement was shown in } \\
37.5 \% \text { of the dexamethasone group } \\
\text { and } 50 \% \text { of the methylprednisolone } \\
\text { group. There was no significant } \\
\text { difference between the two groups } \\
\text { Visual recovery was observed in }\end{array}$ \\
\hline Yip et al. [60] & $\begin{array}{l}\text { Comparative } \\
\text { observational } \\
\text { study }\end{array}$ & 2002 & 21 & $\begin{array}{l}9 \text { patients were treated with } \\
\text { intravenous methylprednisolone, } \\
\text { and } 12 \text { patients were treated } \\
\text { conservatively }\end{array}$ & $\begin{array}{l}44.4 \% \text { of eyes treated with } \\
\text { methylprednisolone and in } 33.3 \% \\
\text { treated conservatively, there were no } \\
\text { differences in visual improvement } \\
\text { between the two groups }\end{array}$ \\
\hline
\end{tabular}


TABle 1: Continued.

\begin{tabular}{|c|c|c|c|c|c|}
\hline Study & Type of the study & Year & $\begin{array}{c}\text { Number of } \\
\text { eyes }\end{array}$ & Treatment protocol & Study result \\
\hline Yang et al. [61] & $\begin{array}{l}\text { Comparative } \\
\text { observational } \\
\text { study }\end{array}$ & 2004 & 42 & $\begin{array}{l}24 \text { patients received treatment with } \\
\text { megadose steroids combined with } \\
\text { optic nerve decompression, and } 18 \\
\text { with megadose methylprednisolone } \\
\text { alone }\end{array}$ & $\begin{array}{c}\text { Patients in a surgical group with an } \\
\text { initial VA of NLP had a better visual } \\
\text { improvement than those in } \\
\text { nonsurgical group }\end{array}$ \\
\hline Entezari et al. [62] & $\begin{array}{l}\text { Randomized } \\
\text { placebo- } \\
\text { controlled clinical } \\
\text { trial }\end{array}$ & 2007 & 31 & $\begin{array}{l}16 \text { eyes received intravenous and oral } \\
\text { corticosteroid, } 15 \text { eyes received } \\
\text { normal saline as the placebo group }\end{array}$ & $\begin{array}{l}\text { There was no difference in visual } \\
\text { acuity improvement between } \\
\text { intravenous high-dose } \\
\text { corticosteroids and placebo }\end{array}$ \\
\hline Lee et al. [15] & $\begin{array}{l}\text { Comparative } \\
\text { observational } \\
\text { study }\end{array}$ & 2010 & 116 & $\begin{array}{c}75 \text { patients received no acute } \\
\text { treatment, and } 41 \text { received steroids } \\
\text { and/or surgery }\end{array}$ & $\begin{array}{l}\text { Of the treated group, } 24 \% \text { and of the } \\
\text { untreated group } 20 \% \text { showed } \\
\text { improvement of VA } \\
\text { There was no difference between the } \\
\text { two groups in improvement of VA }\end{array}$ \\
\hline Pokharel et al. [63] & $\begin{array}{l}\text { Comparative } \\
\text { observational } \\
\text { study }\end{array}$ & 2016 & 10 & $\begin{array}{c}4 \text { cases received intravenous } \\
\text { methylprednisolone, and } 6 \text { cases } \\
\text { were observed without steroid } \\
\text { treatment }\end{array}$ & $\begin{array}{c}\text { The visual recovery after intravenous } \\
\text { steroid treatment was rapid and } \\
\text { beneficial in cases with vision better } \\
\text { than NPL }\end{array}$ \\
\hline Sosin et al. [64] & $\begin{array}{l}\text { Comparative } \\
\text { observational } \\
\text { study }\end{array}$ & 2016 & 109 & $\begin{array}{l}9 \text { patients received intravenous } \\
\text { corticosteroid, } 62 \text { patients } \\
\text { underwent observation, } 31 \text { patients } \\
\text { received surgical intervention, and } \\
\text { the others underwent surgery and } \\
\text { corticosteroid administration }\end{array}$ & $\begin{array}{l}\text { Outcomes following corticosteroid } \\
\text { administration and observation } \\
\text { were comparable }\end{array}$ \\
\hline
\end{tabular}

TABle 2: Summary of the case series evaluating the efficacy of the procedure, surgical indications, and predictive pretreatment factors.

\begin{tabular}{|c|c|c|c|c|c|c|c|}
\hline Study & Year & $\begin{array}{c}\text { The surgical } \\
\text { approach to } \\
\text { decompress } \\
\text { ON }\end{array}$ & $\begin{array}{l}\text { Number } \\
\text { of } \\
\text { patients }\end{array}$ & Conservative treatment & Indication for the surgery & $\begin{array}{l}\text { Report of the } \\
\text { efficacy of the } \\
\text { surgery }\end{array}$ & $\begin{array}{l}\text { Report of predictive } \\
\text { factors }\end{array}$ \\
\hline $\begin{array}{l}\text { Yu et al. } \\
\text { [77] }\end{array}$ & 2018 & $\begin{array}{c}\text { Endoscopic } \\
\text { endonasal }\end{array}$ & 62 & $\begin{array}{c}\text { All cases were } \\
\text { administered by } \\
\text { methylprednisolone } \\
\text { (20 mg/kg/day) and } \\
\text { mouse-derived nerve } \\
\text { growth factor }\end{array}$ & $\begin{array}{l}\text { Patients with no VA } \\
\text { improvement after } \\
\text { intravenous treatment } \\
\text { were recommended to } \\
\text { endoscopic } \\
\text { transethmosphenoid } \\
\text { optic canal } \\
\text { decompression }\end{array}$ & $\begin{array}{l}\text { The overall } \\
\text { visual acuity } \\
\text { improvement } \\
\text { rate after } \\
\text { surgery was } \\
54.84 \%\end{array}$ & $\begin{array}{c}\text { Patients with } \\
\text { residual vision had } \\
\text { better postoperative } \\
\text { visual prognosis and } \\
\text { benefited } \\
\text { Treatment should } \\
\text { still be } \\
\text { recommended even } \\
\text { for cases of delayed } \\
\text { presentation }\end{array}$ \\
\hline $\begin{array}{l}\text { Gupta } \\
\text { and } \\
\text { Gadodia } \\
\text { [78] }\end{array}$ & 2018 & $\begin{array}{c}\text { Endoscopic } \\
\text { endonasal }\end{array}$ & 20 & $\begin{array}{c}\text { All cases received } \\
\text { intravenous } \\
\text { methylprednisolone for } \\
\text { three days before the } \\
\text { surgery }\end{array}$ & $\begin{array}{c}\text { Radiologically evident } \\
\text { bony fractured fragment } \\
\text { impinging on optic nerve } \\
\text { in the intracanalicular } \\
\text { portion, or failure to } \\
\text { improve after } 48 \mathrm{~h} \text { of } \\
\text { steroid therapy, were } \\
\text { indications for surgical } \\
\text { intervention }\end{array}$ & $\begin{array}{l}80 \% \text { of all } \\
\text { patients } \\
\text { benefited from } \\
\text { the surgery }\end{array}$ & $\begin{array}{l}\text { The patients who } \\
\text { were operated } \\
\text { within } 72 \mathrm{~h} \text { were } \\
\text { most benefited } \\
\text { All the patients with } \\
\text { fractures were } \\
\text { benefited }\end{array}$ \\
\hline $\begin{array}{l}\text { Xie et al. } \\
{[79]}\end{array}$ & 2017 & $\begin{array}{c}\text { Endoscopic } \\
\text { endonasal }\end{array}$ & $\begin{array}{l}10 \text { eyes } \\
\text { from } 5 \\
\text { patients }\end{array}$ & $\begin{array}{l}\text { All the patients primarily } \\
\text { treated with high-dose } \\
\text { corticosteroids }\end{array}$ & $\begin{array}{l}\text { All the patients } \\
\text { underwent surgery due to } \\
\text { poor response to medical } \\
\text { therapy }\end{array}$ & $\begin{array}{l}\text { Visual acuity } \\
\text { improved in } \\
30 \% \text { of eyes }\end{array}$ & $\begin{array}{l}\text { Surgical outcomes } \\
\text { depend on both the } \\
\text { timing of surgery } \\
\text { and the severity of } \\
\text { the damage } \\
\text { manifested by initial } \\
\text { visual acuity }\end{array}$ \\
\hline
\end{tabular}


TABLE 2: Continued.

\begin{tabular}{|c|c|c|c|c|c|c|c|}
\hline Study & Year & $\begin{array}{l}\text { The surgical } \\
\text { approach to } \\
\text { decompress } \\
\text { ON }\end{array}$ & $\begin{array}{l}\text { Number } \\
\text { of } \\
\text { patients }\end{array}$ & Conservative treatment & Indication for the surgery & $\begin{array}{l}\text { Report of the } \\
\text { efficacy of the } \\
\text { surgery }\end{array}$ & $\begin{array}{l}\text { Report of predictive } \\
\text { factors }\end{array}$ \\
\hline $\begin{array}{l}\text { Yan et al. } \\
{[80]}\end{array}$ & 2017 & $\begin{array}{c}\text { Endoscopic } \\
\text { endonasal }\end{array}$ & 1275 & $\begin{array}{l}\text { All patients received } \\
\text { intravenous } \\
\text { methylprednisolone of } \\
500-1000 \mathrm{mg} \text { for the first } \\
2 \text { days and half dosage } \\
\text { for the following days }\end{array}$ & $\begin{array}{l}\text { The surgery was } \\
\text { performed on patients } \\
\text { whose VA was no more } \\
\text { than } 20 / 100 \text { with no } \\
\text { improvement after } 4-5 \\
\text { days of conservative } \\
\text { treatment }\end{array}$ & $\begin{array}{c}81.2 \% \text { of } \\
\text { patients } \\
\text { experienced } \\
\text { visual } \\
\text { improvement }\end{array}$ & $\begin{array}{l}\text { The presence and } \\
\text { type of optic canal } \\
\text { fractures may be a } \\
\text { factor of visual } \\
\text { prognosis }\end{array}$ \\
\hline $\begin{array}{l}\text { He et al. } \\
{[81]}\end{array}$ & 2016 & $\begin{array}{c}\text { Endoscopic } \\
\text { endonasal }\end{array}$ & 11 & Not clarified & $\begin{array}{c}\text { Indications for the } \\
\text { surgery was optic nerve } \\
\text { damage in preoperative } \\
\text { VEP scans }\end{array}$ & $\begin{array}{l}\text { Visual acuity } \\
\text { improvement } \\
\text { rate was } 45.5 \%\end{array}$ & $\begin{array}{l}\text { The therapeutic } \\
\text { effect relies on } \\
\text { adequate } \\
\text { decompression of } \\
\text { the optic canal, } \\
\text { timing of the } \\
\text { surgery, and skillful } \\
\text { surgical technique }\end{array}$ \\
\hline $\begin{array}{l}\text { Yang } \\
\text { et al. [82] }\end{array}$ & 2012 & $\begin{array}{c}\text { Endoscopic } \\
\text { endonasal }\end{array}$ & 96 & $\begin{array}{l}\text { Some patients treated } \\
\text { with corticosteroid and } \\
\text { the other not }\end{array}$ & Not clarified & $\begin{array}{l}\text { The overall rate } \\
\text { of effectiveness } \\
\text { was } 40.6 \%\end{array}$ & $\begin{array}{l}\text { No light perception, } \\
\text { undergoing surgery } \\
3 \text { days after trauma, } \\
\text { and hemorrhage } \\
\text { within the ethmoid } \\
\text { and/or sphenoid } \\
\text { sinus were } \\
\text { significantly } \\
\text { associated with } \\
\text { unrecovered visual } \\
\text { acuity }\end{array}$ \\
\hline $\begin{array}{l}\text { Zuo et al. } \\
\text { [83] }\end{array}$ & 2009 & $\begin{array}{c}\text { Endoscopic } \\
\text { endonasal }\end{array}$ & 155 & $\begin{array}{l}\text { All patients received } \\
\text { megadose steroid } \\
\text { therapy }\end{array}$ & $\begin{array}{l}\text { The surgery was } \\
\text { performed after failure of } \\
\text { megadose steroid therapy }\end{array}$ & $\begin{array}{l}\text { The total } \\
\text { effective rate } \\
\text { was } 44.5 \%\end{array}$ & $\begin{array}{l}\text { Residual vision after } \\
\text { trauma and the } \\
\text { interval between } \\
\text { injury and surgery } \\
\text { were significant } \\
\text { prognostic factors }\end{array}$ \\
\hline $\begin{array}{l}\text { Li et al. } \\
{[84]}\end{array}$ & 2008 & $\begin{array}{l}\text { Endoscopic } \\
\text { endonasal }\end{array}$ & 176 & $\begin{array}{l}\text { All patients were treated } \\
\text { with high-dose } \\
\text { dexamethasone } \\
\text { intravenously for three } \\
\text { days, followed by } 20 \mathrm{mg} / \\
\text { day for three days and } \\
10 \mathrm{mg} / \text { day for three days }\end{array}$ & Not clarified & $\begin{array}{l}\text { The total vision } \\
\text { improvement } \\
\text { rate was } 55 \%\end{array}$ & $\begin{array}{c}\text { Early surgery was an } \\
\text { important } \\
\text { prognostic factor } \\
\text { for vision recovery }\end{array}$ \\
\hline
\end{tabular}

their life [44]. Baseline VA is the main predictor of the final outcome; therefore, initially poor VA is associated with limited or no visual recovery [5, 22, 45-47, 85]. Visual recovery and final VA may also be lower in cases with loss of consciousness, lack of visual recovery after 48 hours, absence of visual evoked responses, presence of blood within the posterior ethmoid cells, age over 40 years, lower grade of RAPD, optic canal fracture, and intraconal hematoma and hematoma along the optic nerve $[5,23,36,45,61,86-88]$.

3.6. Experimental Studies on TON. Several animal models have been proposed for studying direct and indirect TON. Optic nerve crush or transection have been used to simulate direct TON, while blast injury [40] and ultrasound-induced neuronal damage [89] have been developed for studying indirect TON. Although these methods have been effective to induce TON, they only look at the damage to optic nerve axons and retinal ganglion cells and do not consider extensive damage, such as brain injury associated with TON. Recently, a murine closed head traumatic brain injury model was proposed, studying indirect TON in the context of traumatic brain injury [90]. In this model, the optic nerve injury occurred at the optic canal level. The results of this model indicated neuroinflammation, gliosis, and axonal degeneration in the optic tract and major axonal targets of the optic nerve axons such as the superior colliculus and lateral geniculate thalamic nucleus. Since a majority of indirect TON cases occurs in patients with head injuries, this model may highlight the association between the TON and the complications of head injuries such as hemorrhage, blood-brain barrier disruption, brain edema, and increased 
intracranial pressure. Concomitant central nervous pathologies can interact with primary and secondary injury mechanisms to influence the progression of an optic nerve injury. The head trauma-based experimental models provide the opportunity to study the potential treatment options for nonvisual brain damages and their impact on optic nerve injuries [90].

\section{Conclusions}

TON is an uncommon vision-threatening disorder that should be considered in a patient with ocular or head trauma and decreased VA. Detection of an afferent pupillary defect in the presence of an intact globe and clear media strongly suggests TON, and neuroimaging must be performed in this clinical setting. Although there is no definitive treatment for TON, the use of EPO can be beneficial in some patients.

\section{Data Availability}

The data supporting this review article are from previously reported studies which have been cited. The extracted information are available from Iman Ansari (imnansari71@ gmail.com) upon request.

\section{Conflicts of Interest}

All authors declare that there are no conflicts of interest regarding the publication of this paper.

\section{References}

[1] J. Chadwick and W. N. Mann, The Medical Works of Hippocrates, Oxford Blackwell Scientific Publications, Hoboken, NJ, USA, 1950

[2] E. J. Atkins, N. J. Newman, and V. Biousse, "Post-traumatic visual loss," Reviews in Neurological Diseases, vol. 5, no. 2, p. 73, 2008.

[3] S. Cirovic, R. M. Bhola, D. R. Hose et al., "Computer modelling study of the mechanism of optic nerve injury in blunt trauma," British Journal of Ophthalmology, vol. 90, no. 6, pp. 778-783, 2006.

[4] N. Sarkies, "Traumatic optic neuropathy," Eye, vol. 18, no. 11, pp. 1122-1125, 2004.

[5] A. Carta, L. Ferrigno, M. Salvo, S. Bianchi-Marzoli, A. Boschi, and F. Carta, "Visual prognosis after indirect traumatic optic neuropathy," Journal of Neurology, Neurosurgery \& Psychiatry, vol. 74, no. 2, pp. 246-248, 2003.

[6] F. B. Walsh, "Pathological-clinical correlations: I. Indirect trauma to the optic nerves and chiasm II. Certain cerebral involvements associated with defective blood supply," Investigative Ophthalmology \& Visual Science, vol. 5, no. 5, pp. 433-449, 1966.

[7] C. E. Gross, J. R. DeKock, W. R. Panje, N. Hershkowitz, and J. Newman, "Evidence for orbital deformation that may contribute to monocular blindness following minor frontal head trauma," Journal of Neurosurgery, vol. 55, no. 6, pp. 963-966, 1981.

[8] G. C. Cockerham, G. L. Goodrich, L. E. D. Weichel et al., "Eye and visual function in traumatic brain injury," The Journal of Rehabilitation Research and Development, vol. 46, no. 6, pp. 811-818, 2009.
[9] J. Edmund and E. Godtfredsen, "Unilateral optic atrophy following head injury," Acta Ophthalmologica, vol. 41, no. 6, pp. 693-697, 1963.

[10] H. Nau, L. Gerhard, M. Foerster, H. C. Nahser, V. Reinhardt, and T. Joka, "Optic nerve trauma: clinical, electrophysiological and histological remarks," Acta Neurochirurgica, vol. 89, no. 1-2, pp. 16-27, 1987.

[11] F. Pirouzmand, "Epidemiological trends of traumatic optic nerve injuries in the largest Canadian adult trauma center," Journal of Craniofacial Surgery, vol. 23, no. 2, pp. 516-520, 2012.

[12] S. B. Urolagin, S. M. Kotrashetti, T. P. Kale, and L. J. Balihallimath, "Traumatic optic neuropathy after maxillofacial trauma: a review of 8 cases," Journal of Oral and Maxillofacial Surgery, vol. 70, no. 5, pp. 1123-1130, 2012.

[13] R. L. Anderson, W. R. Panje, and C. E. Gross, "Optic nerve blindness following blunt forehead trauma," Ophthalmology, vol. 89, no. 5, pp. 445-455, 1982.

[14] M. R. Crompton, "Visual lesions in closed head injury," Brain, vol. 93, no. 4, pp. 785-792, 1970.

[15] V. Lee, R. L. Ford, W. Xing, C. Bunce, and B. Foot, "Surveillance of traumatic optic neuropathy in the UK," Eye, vol. 24, no. 2, pp. 240-250, 2010.

[16] N. Goldenberg-Cohen, N. R. Miller, and M. X. Repka, "Traumatic optic neuropathy in children and adolescents," Journal of American Association for Pediatric Ophthalmology and Strabismus, vol. 8, no. 1, pp. 20-27, 2004.

[17] A. K. Mahapatra and D. A. Tandon, "Traumatic optic neuropathy in children: a prospective study," Pediatric Neurosurgery, vol. 19, no. 1, pp. 34-39, 1993.

[18] K. D. Steinsapir and R. A. Goldberg, "Traumatic optic neuropathy," Survey of Ophthalmology, vol. 38, pp. 487-518, 1994.

[19] A. Thale, K. Jungmann, and F. Paulsen, "Morphological studies of the optic canal," Orbit, vol. 21, no. 2, pp. 131-137, 2002.

[20] D. H. Smith and D. F. Meaney, "Axonal damage in traumatic brain injury," The Neuroscientist, vol. 6, no. 6, pp. 483-495, 2000.

[21] E. L. Singman, N. Daphalapurkar, H. White et al., "Indirect traumatic optic neuropathy," Military Medical Research, vol. 3, no. 1, pp. 1-6, 2016.

[22] L. A. Levin, R. W. Beck, M. P. Joseph, S. Seiff, R. Kraker, and I. Group, "The treatment of traumatic optic neuropathy," Ophthalmology, vol. 106, no. 7, pp. 1268-1277, 1999.

[23] B. H. Wang, B. C. Robertson, J. A. Girotto et al., "Traumatic optic neuropathy: a review of 61 patients," Plastic and Reconstructive Surgery, vol. 107, no. 7, pp. 1655-1664, 2001.

[24] S. Lessell, "Indirect optic nerve trauma," Archives of Ophthalmology, vol. 107, no. 3, pp. 382-386, 1989.

[25] P. Y.-W. Man, "Traumatic optic neuropathy-clinical features and management issues," Taiwan Journal of Ophthalmology, vol. 5, no. 1, pp. 3-8, 2015.

[26] S. R. Seiff, M. S. Berger, L. H. Pitts, J. Guyon, and J. Guyon, "Computed tomographic evaluation of the optic canal in sudden traumatic blindness," American Journal of Ophthalmology, vol. 98, no. 6, pp. 751-755, 1984.

[27] S. J. Manfredi, M. R. Raji, P. M. Sprinkle, G. W. Weinstein, L. M. Minardi, and T. J. Swanson, "Computerized tomographic scan findings in facial fractures associated with blindness," Plastic and Reconstructive Surgery, vol. 68, no. 4, pp. 479-490, 1981.

[28] S. Takehara, T. Tanaka, K. Uemura et al., "Optic nerve injury demonstrated by MRI with STIR sequences," Neuroradiology, vol. 36, no. 7, pp. 512-514, 1994. 
[29] B. T. Hathiram, V. S. Khattar, H. P. Sonawane, and P. J. Watve, "Traumatic optic neuropathy-our experience," Indian Journal of Otolaryngology and Head \& Neck Surgery, vol. 62 , no. 3, pp. 229-235, 2010.

[30] H.-H. Tsai, S.-F. Jeng, T.-S. Lin, N.-S. Kueh, and C.-H. Hsieh, "Predictive value of computed tomography in visual outcome in indirect traumatic optic neuropathy complicated with periorbital facial bone fracture," Clinical Neurology and Neurosurgery, vol. 107, no. 3, pp. 200-206, 2005.

[31] U. K. Bodanapally, K. Shanmuganathan, R. K. Shin et al., "Hyperintense optic nerve due to diffusion restriction: diffusion-weighted imaging in traumatic optic neuropathy," American Journal of Neuroradiology, vol. 36, no. 8, pp. 1536-1541, 2015.

[32] J. Li, W. Shi, M. Li et al., "Time-dependent diffusion tensor changes of optic nerve in patients with indirect traumatic optic neuropathy," Acta Radiologica, vol. 55, no. 7, pp. 855-863, 2014.

[33] A. Mahapatra, "Visual evoked potentials in optic nerve injury. Does it merit a mention?" Acta Neurochirurgica, vol. 112, no. 1-2, pp. 47-49, 1991.

[34] A. Mahapatra, "Delayed recovery from indirect optic nerve injury. A report of two unusual cases," Journal of Neurosurgical Sciences, vol. 36, no. 3, pp. 151-153, 1992.

[35] S. Yeh and R. Foroozan, "Orbital apex syndrome," Current Opinion in Ophthalmology, vol. 15, no. 6, pp. 490-498, 2004.

[36] M. D. Holmes and B. S. Sires, "Flash visual evoked potentials predict visual outcome in traumatic optic neuropathy," Ophthalmic Plastic \& Reconstructive Surgery, vol. 20, no. 5, pp. 342-346, 2004

[37] S. Mine, I. Yamakami, A. Yamaura et al., "Outcome of traumatic optic neuropathy. Comparison between surgical and nonsurgical treatment," Acta Neurochirurgica, vol. 141, no. 1, pp. 27-30, 1999.

[38] A. Kumaran, G. Sundar, and L. Chye, "Traumatic optic neuropathy: a review," Craniomaxillofacial Trauma \& Reconstruction, vol. 8, no. 1, pp. 31-41, 2015.

[39] L. P. Cunha, L. V. F. Costa-Cunha, R. F. S. Malta, and M. L. R. Monteiro, "Comparison between retinal nerve fiber layer and macular thickness measured with OCT detecting progressive axonal loss following traumatic optic neuropathy," Arquivos brasileiros de oftalmologia, vol. 72, no. 5, pp. 622-625, 2009.

[40] K. Mohan, H. Kecova, E. Hernandez-Merino, R. H. Kardon, and M. M. Harper, "Retinal ganglion cell damage in an experimental rodent model of blast-mediated traumatic brain injury," Investigative Opthalmology \& Visual Science, vol. 54, no. 5, pp. 3440-3450, 2013.

[41] B. C. Chauhan, K. T. Stevens, J. M. Levesque et al., "Longitudinal in vivo imaging of retinal ganglion cells and retinal thickness changes following optic nerve injury in mice," PLoS One, vol. 7, no. 6, Article ID e40352, 2012.

[42] S. Wei, H.-z. Wang, W.-x. Song, W.-l. Yang, W.-y. LI, and N.-l. Wang, "Axonal loss and blood flow disturbances in the natural course of indirect traumatic optic neuropathy," Chinese Medical Journal, vol. 126, no. 7, pp. 1292-1297, 2013.

[43] A. Ustymowicz, Z. Mariak, I. Obuchowska, Z. Mariak, and J. Kochanowicz, "Blood flow disturbances in the central retinal artery in patients with traumatic optic neuropathy," Medical Science Monitor: International Medical Journal of Experimental and Clinical Research, vol. 15, no. 7, pp. CR366-CR371, 2009.

[44] A. Carta, L. Ferrigno, R. Leaci, A. Kosmarikou, E. Zola, and S. Gomarasca, "Long-term outcome after conservative treatment of indirect traumatic optic neuropathy," European Journal of Ophthalmology, vol. 16, no. 6, pp. 847-850, 2006.

[45] P. I. Chou, A. A. Sadun, Y. C. Chen, W. Y. Su, S. Z. Lin, and C. C. Lee, "Clinical experiences in the management of traumatic optic neuropathy," Neuro-Ophthalmology, vol. 16, no. 6, pp. 325-336, 1996.

[46] M. W. Cook, L. A. Levin, M. P. Joseph, and E. F. Pinczower, "Traumatic optic neuropathy: a meta-analysis," Archives of Otolaryngology-Head and Neck Surgery, vol. 122, no. 4, pp. 389-392, 1996.

[47] S. R. Seiff, "High dose corticosteroids for treatment of vision loss due to indirect injury to the optic nerve," Ophthalmic Surgery, Lasers and Imaging Retina, vol. 21, no. 6, pp. 389-395, 1990.

[48] A. Kanamori, M. Nakamura, Y. Yamada, and A. Negi, "Longitudinal study of retinal nerve fiber layer thickness and ganglion cell complex in traumatic optic neuropathy," Archives of Ophthalmology, vol. 130, no. 8, pp. 1067-1069, 2012.

[49] E. D. Hall and J. M. Braughler, "Corticosteroid therapy in experimental cord injury," Journal of Neurosurgery, vol. 61, no. 4, pp. 805-806, 1984.

[50] E. D. Hall, "The neuroprotective pharmacology of methylprednisolone," Journal of Neurosurgery, vol. 76, no. 1, pp. 13-22, 1992.

[51] M. Ohlsson, U. Westerlund, I. A. Langmoen, and M. Svensson, "Methylprednisolone treatment does not influence axonal regeneration or degeneration following optic nerve injury in the adult rat," Journal of Neuro-Ophthalmology, vol. 24, no. 1, pp. 11-18, 2004.

[52] K. D. Steinsapir, R. A. Goldberg, S. Sinha, and D. A. Hovda, "Methylprednisolone exacerbates axonal loss following optic nerve trauma in rats," Restorative Neurology and Neuroscience, vol. 17, no. 4, pp. 157-163, 2000.

[53] H. Lew, S. Y. Lee, J. W. Jang, H. Y. Kim, S. J. Kang, and S. J. Kim, "The effects of high-dose corticosteroid therapy on optic nerve head blood flow in experimental traumatic optic neuropathy," Ophthalmic Research, vol. 31, no. 6, pp. 463-470, 1999.

[54] M. B. Bracken, M. J. Shepard, W. F. Collins et al., "A randomized, controlled trial of methylprednisolone or naloxone in the treatment of acute spinal-cord injury," New England Journal of Medicine, vol. 322, no. 20, pp. 1405-1411, 1990.

[55] M. B. Bracken, "Steroids for acute spinal cord injury," Cochrane Database of Systematic Reviews, vol. 1, no. 1, 2002.

[56] T. C. Spoor, D. B. Lensink, M. J. Wilkinson, and W. C. Hartel, "Treatment of traumatic optic neuropathy with corticosteroids," American Journal of Ophthalmology, vol. 110, no. 6, pp. 665-669, 1990.

[57] J. A. Mauriello, J. DeLuca, A. Krieger, M. Schulder, and L. Frohman, "Management of traumatic optic neuropathy-a study of 23 patients," British Journal of Ophthalmology, vol. 76, no. 6, pp. 349-352, 1992.

[58] K. Kitthaweesin, "Dexamethasone and methylprednisolone in treatment of indirect traumatic optic neuropathy," Journal of the Medical Association of Thailand, vol. 84, pp. 628-634, 2001.

[59] W. Chuenkongkaew and N. Chirapapaisan, "A prospective randomized trial of megadose methylprednisolone and high dose dexamethasone for traumatic optic neuropathy," Journal of the Medical Association of Thailand, vol. 85, no. 5, p. 597, 2002.

[60] C.-C. Yip, N.-W. Chng, K.-G. Au Eong, W.-J. Heng, T.-H. Lim, and W.-K. Lim, "Low-dose intravenous methylprednisolone or conservative treatment in the management of 
traumatic optic neuropathy," European Journal of Ophthalmology, vol. 12, no. 4, pp. 309-314, 2002.

[61] W.-G. Yang, C.-T. Chen, P.-K. Tsay, G. H. de Villa, Y.-J. Tsai, and Y.-R. Chen, "Outcome for traumatic optic neuropathysurgical versus nonsurgical treatment," Annals of Plastic Surgery, vol. 52, no. 1, pp. 36-42, 2004.

[62] M. Entezari, Z. Rajavi, N. Sedighi, N. Daftarian, and M. Sanagoo, "High-dose intravenous methylprednisolone in recent traumatic optic neuropathy; a randomized doublemasked placebo-controlled clinical trial," Graefe's Archive for Clinical and Experimental Ophthalmology, vol. 245, no. 9, pp. 1267-1271, 2007.

[63] S. Pokharel, D. Sherpa, R. Shrestha et al., "Visual outcome after treatment with high dose intravenous methylprednisolone in indirect traumatic optic neuropathy," Journal of Nepal Health Research Council, vol. 14, no. 32, pp. 1-6, 2016.

[64] M. Sosin, C. De La Cruz, G. S. Mundinger et al., "Treatment outcomes following traumatic optic neuropathy," Plastic and Reconstructive Surgery, vol. 137, no. 1, pp. 231-238, 2016.

[65] M. B. Kashkouli, F. Pakdel, M. S. Sanjari et al., "Erythropoietin: a novel treatment for traumatic optic neuropathy-a pilot study," Graefe's Archive for Clinical and Experimental Ophthalmology, vol. 249, no. 5, pp. 731-736, 2011.

[66] M. Entezari, M. Esmaeili, and M. Yaseri, "A pilot study of the effect of intravenous erythropoetin on improvement of visual function in patients with recent indirect traumatic optic neuropathy," Graefe's Archive for Clinical and Experimental Ophthalmology, vol. 252, no. 8, pp. 1309-1313, 2014.

[67] M. B. Kashkouli, S. Yousefi, M. Nojomi et al., "Traumatic optic neuropathy treatment trial (TONTT): open label, phase 3, multicenter, semi-experimental trial," Graefe's Archive for Clinical and Experimental Ophthalmology, vol. 256, no. 1, pp. 209-218, 2018.

[68] C. T. Collaborators, "Final results of MRC CRASH, a randomised placebo-controlled trial of intravenous corticosteroid in adults with head injury-outcomes at 6 months," The Lancet, vol. 365, no. 9475, pp. 1957-1959, 2005.

[69] R. W. Beck, P. A. Cleary, M. M. Anderson Jr. et al., “A randomized, controlled trial of corticosteroids in the treatment of acute optic neuritis," New England Journal of Medicine, vol. 326, no. 9, pp. 581-588, 1992.

[70] H.-J. Oh, D.-G. Yeo, and S.-C. Hwang, "Surgical treatment for traumatic optic neuropathy," Korean Journal of Neurotrauma, vol. 14, no. 2, pp. 55-60, 2018.

[71] T.-M. Wohlrab, S. Maas, and J. P. De Carpentier, "Surgical decompression in traumatic optic neuropathy," Acta Ophthalmologica Scandinavica, vol. 80, no. 3, pp. 287-293, 2002.

[72] E. Emanuelli, M. Bignami, E. Digilio, S. Fusetti, T. Volo, and P. Castelnuovo, "Post-traumatic optic neuropathy: our surgical and medical protocol," European Archives of OtoRhino-Laryngology, vol. 272, no. 11, pp. 3301-3309, 2015.

[73] S. S. Dhaliwal, L. J. Sowerby, and B. W. Rotenberg, "Timing of endoscopic surgical decompression in traumatic optic neuropathy: a systematic review of the literature," International Forum of Allergy \& Rhinology, Wiley, Hoboken, NJ, USA, 2016.

[74] L. Rigante, A. Evins, L. Berra, A. Beer-Furlan, P. Stieg, and A. Bernardo, "Optic nerve decompression through a supraorbital approach," Journal of Neurological Surgery Part B: Skull Base, vol. 76, no. 3, p. 239, 2015.

[75] X. Wang, W. Wu, H. Zhang, and Q. Lan, "Endoscopic optic nerve decompression through supraorbital keyhole extradural approach: a cadaveric study," Turkish Neurosurgery, vol. 27, no. 2, pp. 212-216, 2017.
[76] A. Di Somma, L. M. Cavallo, M. de Notaris et al., "Endoscopic endonasal medial-to-lateral and transorbital lateral-to-medial optic nerve decompression: an anatomical study with surgical implications," Journal of Neurosurgery, vol. 127, no. 1, pp. 199-208, 2016.

[77] B. Yu, Y. Chen, Y. Ma, Y. Tu, and W. Wu, "Outcome of endoscopic trans-ethmosphenoid optic canal decompression for indirect traumatic optic neuropathy in children," $B M C$ Ophthalmology, vol. 18, no. 1, p. 152, 2018.

[78] D. Gupta and M. Gadodia, "Transnasal endoscopic optic nerve decompression in post traumatic optic neuropathy," Indian Journal of Otolaryngology and Head \& Neck Surgery, vol. 70, no. 1, pp. 49-52, 2018.

[79] D. Xie, H. Yu, J. Ju, and L. Zhang, "The outcome of endoscopic optic nerve decompression for bilateral traumatic optic neuropathy," Journal of Craniofacial Surgery, vol. 28, no. 4, pp. 1024-1026, 2017.

[80] W. Yan, Y. Chen, Z. Qian et al., "Incidence of optic canal fracture in the traumatic optic neuropathy and its effect on the visual outcome," British Journal of Ophthalmology, vol. 101, no. 3, pp. 261-267, 2017.

[81] Z.-H. He, Z.-B. Lan, A. Xiong et al., "Endoscopic decompression of the optic canal for traumatic optic neuropathy," Chinese Journal of Traumatology, vol. 19, no. 6, pp. 330-332, 2016.

[82] Q.-T. Yang, G.-H. Zhang, X. Liu, J. Ye, and Y. Li, "The therapeutic efficacy of endoscopic optic nerve decompression and its effects on the prognoses of 96 cases of traumatic optic neuropathy," The Journal of Trauma and Acute Care Surgery, vol. 72, no. 5, pp. 1350-1355, 2012.

[83] K.-J. Zuo, J.-B. Shi, W.-P. Wen, H.-X. Chen, X.-M. Zhang, and $\mathrm{G}$. Xu, "Transnasal endoscopic optic nerve decompression for traumatic optic neuropathy: analysis of 155 cases," Zhonghua Yi Xue Za Zhi, vol. 89, no. 6, pp. 389-392, 2009.

[84] H. Li, B. Zhou, J. Shi, L. Cheng, W. Wen, and G. Xu, "Treatment of traumatic optic neuropathy: our experience of endoscopic optic nerve decompression," The Journal of Laryngology \& Otology, vol. 122, no. 12, p. 1325, 2008.

[85] K. D. Steinsapir, "Treatment of traumatic optic neuropathy with high-dose corticosteroid," Journal of Neuro-Ophthalmology, vol. 26, no. 1, pp. 65-67, 2006.

[86] S. A. Tabatabaei, M. Soleimani, M. Alizadeh et al., "Predictive value of visual evoked potentials, relative afferent pupillary defect, and orbital fractures in patients with traumatic optic neuropathy," Clinical Ophthalmology (Auckland, NZ), vol. 5, p. 1021, 2011.

[87] M. G. Rajiniganth, A. K. Gupta, A. Gupta, and J. R. Bapuraj, "Traumatic optic neuropathy," Archives of OtolaryngologyHead \& Neck Surgery, vol. 129, no. 11, pp. 1203-1206, 2003.

[88] R. P. Reddy, U. K. Bodanapally, K. Shanmuganathan et al., "Traumatic optic neuropathy: facial CT findings affecting visual acuity," Emergency Radiology, vol. 22, no. 4, pp. 351-356, 2015.

[89] W. Tao, G. Dvoriantchikova, C. T. Brian et al., "A novel mouse model of traumatic optic neuropathy using external ultrasound energy to achieve focal, indirect optic nerve injury," Scientific Reports, vol. 7, no. 1, pp. 1-14, 2017.

[90] N. K. Evanson, F. Guilhaume-Correa, J. P. Herman, and M. D. Goodman, "Optic tract injury after closed head traumatic brain injury in mice: a model of indirect traumatic optic neuropathy," PLoS One, vol. 13, no. 5, Article ID e0197346, 2018. 